\title{
Steam Reforming of Natural Gas: A Value Addition to Natural Gas Utilization in Nigeria
}

\author{
Minister Ezekiel Obonukut ${ }^{*}$, Sunday Boladale Alabi and Perpetua George Bassey \\ Department of Chemical \& Petroleum Engineering, University of Uyo, Uyo, P.M.B. 1017, Akwa Ibom State, Nigeria
}

\begin{abstract}
Petrochemicals play a vital role in the economy of any nation. The products of the industry are the building blocks in many industries as they deepen the forward and backward linkages of the petroleum sector with the rest of the economy. The industry uses a variety of hydrocarbon feedstock such as different cuts of naphtha from refinery and natural gas. One of the problems facing the industry is lack of reliable feedstock supplies. Nigeria has the potential to be a major petrochemicals producer. With proven gas reserves currently estimated at $187 \mathrm{tcf}$, not much has been accomplished with respect to the effective exploitation and utilization of this resource as most of the nation's natural gas production has been flared, liquefied for export or re-injected to enhance greater crude oil recovery. It has become imperative to further find ways to exploit and utilize the nation's natural gas reserves and translate it to the improvement of the nation's economy. Steam reforming of natural gas is one of the avenues for conversion of natural gas to petrochemicals. This paper, however, reviews various ways of utilizing natural gas, examines the process details of steam reforming of natural gas as a route to optimized natural gas utilization and industrialization in Nigeria. Syngas (synthesis gas) is a versatile feedstock for most petrochemicals and chemical intermediates. Thus utilizing natural gas in this way would strengthen the petrochemical industry making it possible for the country to change from raw materials to value-added products supplier, boost the economy and solve the "hydra-headed" problem of unemployment in Nigeria with its multiplier employment effect.
\end{abstract}

Key words: Natural gas, petrochemicals, steam reforming, synthesis gas.

\section{Introduction}

Fossil fuel provides a great portion of the world's growing energy need and the situation is likely to remain so in the next decade [1]. Presently, about 20\% of all the primary energy requirements of the world are provided by natural gas; though it was once an unwanted by-product of crude oil production. This development has been recorded in only a few years with the increased availability of the gas resources from different countries [2]. The total global annual gas consumption is forecasted to rise to 2.9 trillion cubic meters by 2015, accounting for approximately $27 \%$ of the total primary energy supply [3]. World gas reserves are more evenly distributed compared to oil reserves, with one-third in Russia and Central Asia, one-third in the Middle East and one-third in other parts of the world. This condition favors a more open

*Corresponding author: Minister Obonukut, master, research field: petroleum processing engineering. market and less geo-political tension than crude oil markets and thus, is conducive to the long-term development of gas projects [4].

As oil shortage looms in the future, it becomes a concern for scientists and engineers to use natural gas as an alternative source of energy and a feedstock in chemical industries. In fact, countries that have a large supply of natural gas have started investing in research in this area [5]. Many isolated sources of natural gas, either residual or in stranded puddles remain unexploited because they are distant from an existing pipeline or waterway and/or too small for local usage. The drive to utilize large stranded gas resources, coupled with prudent utilization of gas resource and environmental considerations, led to the development in LNG (liquefied natural gas), GTL (gas-to-liquid), and F-T (Fischer-Tropsch) technologies. Gas utilization projects cover power generation, production of chemicals, NGL (natural gas liquids), 
LNG extraction and LNG [1]. Technologies such as CNG (compressed natural gas) and gas-to-power, using HVDC (high voltage direct current) to move gas or electricity derived from it over short and medium distance are attracting interest of specialized markets. CNG is also used for the purpose of enhanced oil recovery. The process of converting gas to solids in the form of hydrates, though still being researched, has the potential to transport and store gas in the future. Steam reforming of natural gas is a catalyzed process which gives a blend of primary hydrogen and carbon monoxide-syngas (synthesis gas) forms the basis for diverse end products that are deployed in a wide range of industrial scenarios [6].

Crude oil currently accounts for over $90 \%$ of the Nigeria's foreign exchange earnings and there is as much gas as there is oil, then the increasing demand for gas brings hope for increased revenue [7]. It therefore becomes important and appropriate for Nigeria to develop her vast natural gas reserves to serve her economy, strengthen regional co-operation and meet expanding demand in different world markets. Certainly, gas has some positive macroeconomic implications for a country like Nigeria. This paper, therefore, reviews various ways of utilizing natural gas with the aim of finding the best route for its industrial application with particular emphasis on Nigeria.

\section{Advances in Natural Gas Utilization}

Natural gas which is almost an embarrassing and unwanted by-product or a co-product of crude oil production occurs naturally in association with crude oil in a crude oil well (associated gas), or alone as a gas in a gas well (non-associated gas). Non-associated gas is somewhat clean and requires little processing while associated gas is highly contaminated and requires much processing [8]. Natural gas processing is defined as the cleaning of natural gas to remove impurities such as oil and condensates, condensed water and water vapor, NGL, etc.. Natural gas processing to a large extent depends on the gas buyers' specification and the end use of the gas. Natural gas coming from reservoirs is treated as follows:

(1) Acid gas removal, where acid gases are removed to avoid $\mathrm{CO}_{2}$ and $\mathrm{H}_{2} \mathrm{~S}$ freezing in the early stages of the liquefaction process;

(2) Dehydration to remove the water from the gas to avoid hydrates formation in pipelines and vessels;

(3) Mercury removal, since the presence of mercury causes corrosion problems in the aluminum heat exchangers used in the liquefaction process.

The processed natural gas can then be utilized in the following ways:

LNG: The LNG technologies involve liquefaction, shipping and re-gasification, and delivery into the pipeline grid. When natural gas is cooled and liquefied through cryogenic processes at a temperature of appropriately $-260^{\circ} \mathrm{F}\left(-162^{\circ} \mathrm{C}\right), \mathrm{LNG}$ is formed. As a result of this, natural gas volume is reduced to one-six hundredth, allowing its transportation by specialized LNG tanker ships over long distances. This liquefaction method of utilizing gas has the advantage of reducing NG (natural gas) to $1 / 600$ of its original volume, making it economical for long distance transportation mainly for export $[9,10]$.

CNG: Smaller and isolated hydrocarbon resources stranded by geologic impediments or located in politically hostile environments cannot be transported by pipelines. Also, it is not economical to transport small quantities of gas particularly in offshore locations via LNG. The most efficient alternative channel of harnessing stranded gas is CNG technology [11]. When natural gas is compressed at low or ambient temperature to a density of about $150-250 \mathrm{~kg} / \mathrm{m}^{3}$ compared to $600 \mathrm{~kg} / \mathrm{m}^{3}$ for LNG, the fluid obtained is called CNG. The CNG is filled into large pressure bottles of about $110 \mathrm{~cm}$ diameter and $36 \mathrm{~m}$ length, and transported by ship to a receiving terminal. CNG is a safe and environmentally friendly fuel [7]. It provides operations with reduced noise pollution, produces non-toxic vapor and it provides toxic soot pollution 
reduction by about 75\%-90\% with smog forming pollution reduction by about $25 \%$ compared to conventional automobile fuel [2].

Gas-To-Power (Gas-Fired Power Generation): Natural gas can be used to generate electricity in a variety of ways. The most basic natural gas fired electric generation consists of a steam generation unit, where fossils fuels are burned in a boiler to raise steam, which then turns a turbine to generate electricity [8]. Gas turbines and combustion engines are also used to generate electricity. In these types of units, instead of raising steam to turn a turbine, hot gases from burning fossils fuels (particularly natural gas) are used to turn the turbine and generate electricity. Gas turbine and combustion engine plants are traditionally used primarily for peak-load demands, as it is possible to quickly and easily turn them on. These plants have increased in popularity due to advances in technology and the availability of natural gas. However, they are still traditionally slightly less efficient than large steam-driven power plants. Many of the new natural gas fired power plants are known as "combined-cycle" units. In these types of generating facilities, there are both gas turbine and steam units. The gas turbine operates in much the same way as a normal gas turbine, using the hot gases released from burning natural gas to turn a turbine and generate electricity. In combined-cycle plants, the waste heat from the gas-turbine process is directed towards generating steam, which is then used to generate electricity much like a steam unit. Because of this efficient use of the heat energy released from the natural gas, combined-cycle plants are much more efficient than steam units or gas turbines alone. In fact, combined plants can achieve thermal efficiencies of up to $50 \%-60 \%$ [8].

GTS (Gas-To-Solid) / NGH (Natural Gas Hydrates): GTS/NGH are ice-like solid crystalline compounds formed by the chemical combination of natural gas and water (where individual gas molecules exist with cages of water molecules $\mathrm{CH}_{4} \mathrm{nH}_{2} \mathrm{O}$ where $\mathrm{n} \geq 5.75$ ), under pressure and temperature considerably higher than the freezing point of water [11]. In the presence of free water, hydrate will form when temperature is below a typical temperature called hydrate temperature. $\mathrm{NGH}$ can contain up to $160 \mathrm{~m}^{3}$ of methane per $1 \mathrm{~m}^{3}$ of hydrate. Hydrate technology development has focused on using gas hydrates to convert GTS to transport natural gas to market as a low cost solution to managing associated gas in regions lacking in gas infrastructure and/or market. Gas hydrates form naturally in certain subsea sediments and it may offer another solution for the gas supply chain. Major quantities could be stored because the volumes are reduced by a factor of about 180 which is less than the 200 volumes and 600 volumes reductions for $\mathrm{CNG}$ and $\mathrm{LNG}$, respectively.

Compared to alternative technologies such as LNG and GTL, GTS hydrates conversion is relatively simple, low cost and does not require complex processes or extremes of pressure or temperature. It can be small-scale, modular and particularly appropriate for offshore associated gas application. Put simply, the hydrate production concept amounts to adding water to natural gas and "stir" [8]. However, a comprehensive understanding of hydrate behavior is necessary to design the technology for transoceanic gas transportation. Gas hydrates could be produced by contacting natural gas with water at $10{ }^{\circ} \mathrm{C}$ and 20 bars, after which the temperature is lowered to $-10{ }^{\circ} \mathrm{C}$ for the gas molecules to be trapped in metastable ice structures that form solids at ambient temperature. Gas hydrates crystals resemble ice in appearance but do not have the solid structure of ice. They are much less dense and exhibit properties that are generally associated with chemical substance; the main frame work of their structure is water and the hydrate molecules occupying the void space in the crystal structure are held together by the chemically weak bonds with the water [11].

GTL (gas-to-petrochemicals): Generally, natural gas can be directly or indirectly converted to 
petrochemicals. Holmen [12] reviewed various ways in which natural gas can be directly converted to petrochemicals. The indirect method involves converting natural gas to syngas first, and then converting the resultant gas (syngas) to any petrochemical products of interest. However, the indirect method is the conventional method of utilizing natural gas to petrochemical, as it is more economical than the direct method [13-16]. Hence, this paper critically reviews syngas route to petrochemicals from natural gas as a more viable option of utilizing natural gas.

Syngas production process involves a chemical reaction of dry natural gas (methane) with either oxygen or steam using reformer which then produce a mixture of hydrogen and carbon monoxide $\left(\mathrm{H}_{2}-\mathrm{CO}\right)$. The production of an ideal syngas calls for a $\mathrm{H}_{2} / \mathrm{CO}$ ratio of 2:1. There are four main technologies used in the all-important reforming stage [6]. These can be broken into two categories: three catalytic modelsSMR (steam methane reforming), HER (heat exchange reforming) and ATR (auto thermal reforming) and the non-catalytic POXR (partial oxidation reforming). Details of these technologies were considered in this paper. Three of these technologies use natural gas feedstock [17-23]. They are SMR, POXR, and ATR. The conversion of $\mathrm{H}_{2}$ and $\mathrm{CO}$ mixture to liquid hydrocarbons is based on F-T catalytic synthesis which ideally calls for a $\mathrm{H}_{2} / \mathrm{CO}$ ratio of $2: 1$.

F-T synthesis can be used to produce liquid alkanes (paraffins), liquid alkenes (olefins) and oxygenates such as alcohols [24, 25]. F-T products are further treated to maximize their sales value or to meet particular market needs [26]. Consequently, the upgrading of paraffins and olefins can be done by using standard hydrocracking, hydrogenation, oligomerization and isomerization processes. The breakdown of the fractions of GTL is naphtha $15 \%-25 \%$, middle distillates $65 \%-85 \%$, and associated LPG condensates about 0-30\% [27].

\section{Nigeria's Achievements in Utilizing Natural Gas Reserves}

As at 2014, Nigeria's gas reserves were estimated at 187 trillion cubic feet (or 30 billion barrels of oil equivalent) which is almost as high as the country's estimated oil reserves of 30 billion barrels [1]. Nigeria's achievements in utilizing natural gas reserves include Nigeria LNG plant, Brass LNG Plant, Escravos GLT Plant, Bonny Non-Associated Gas Plant, West Niger Delta LNG Plant, Olokola LNG Project, Bonny Island Gas and Power Plant, Nigeria Gas Company, Akwa Ibom Gas Plant, Ovia's \$1.5 billion methanol and petrochemical plant and some thermal power plants. Unfortunately, most of these projects have not reached operational stage [28-30]; consequently, they failed to strengthen the country's petrochemical industry which is pivotal to industrial manufacturing which help to deepen the forward and backward linkages of the petroleum sector with the rest of the economy [31]. Hence, gas utilization in Nigeria is still inadequate when compared to those of other oil and gas producing nations. In the following sections, the need for syngas as a versatile feedstock, various pathways from natural gas to syngas and the regrettable absence of syngas use in the Nigerian petrochemical industry are discussed.

\section{Syngas: A Versatile Feedstock for Chemical Intermediates}

From the agrochemicals sector to steel production, from petroleum refineries to chemical production, many sectors of the CPI (chemical process industries) would grind to a halt overnight without one crucial ingredient: syngas [6]. Steam reforming of natural gas is a catalyzed process in which methane, which constitutes about $80 \%$ or more of natural gas [32] and steam are chemically reconstituted to form a mixture of $\mathrm{CO}$ and $\mathrm{H}_{2}$. The $\mathrm{CO}-\mathrm{H}_{2}$ mixture is called syngas, which forms the basis for most petrochemicals and chemical intermediates manufacture. Syngas can be defined in a broader sense as a mixture of gases in 
suitable proportions for production of intermediate or final industrial products without adding further reactants [33]. In the broader sense, syngas can also be, besides $\mathrm{CO}-\mathrm{H}_{2}$ mixture, mixture of $\mathrm{N}_{2}-\mathrm{H}_{2}$ (for ammonia synthesis), or $\mathrm{CO}-\mathrm{H}_{2}$-Olefins (for oxo alcohols) [33]. As syngas is not usually stored in its component form, due to difficulty of liquefaction, their plants are often sited adjacent to downstream plants utilizing the syngas as feedstock (although gas-line transportation over short distances to final use is also practicable). Depending on the stoichiometric needs of the downstream reaction, the $\mathrm{H}_{2} / \mathrm{CO}$ ratio is often adjusted. For example, the optimal mole ratio is $\mathrm{H}_{2} / \mathrm{CO}=2$ for methanol production; $\mathrm{H}_{2} / \mathrm{N}_{2}=3$ for $\mathrm{NH}_{3}$ production; $\mathrm{H}_{2} / \mathrm{CO}=2$ for alkenes production; and pure $\mathrm{CO}$ for formic acetic acid. These compounds can then be utilized as final products or as intermediates for the manufacture of final products such as formaldehyde, oxygenates such as MTBE (methyl tertiary butyl ether), fertilizer, plastics and resins of high grades, and a whole vast range of other commercially viable chemical products. Fig. 1 illustrates the syngas routes to some of these products.

\section{Various Pathways from Natural Gas to Syngas}

Syngas, synthetic gas or producer gas, can be produced from a variety of different materials that contain carbon. Syngas, in its simplest form is composed of two diatomic molecules, $\mathrm{CO}$ and $\mathrm{H}_{2}$ [35], which provide the chemical building blocks upon which an entire field of fuel science and chemical technology is based. It is used primarily as feedstock in downstream manufacture processes and can be produced from any hydrocarbon feedstock. Broadly speaking, syngas is generated by one of two ways: reforming and gasification. Using methane reforming process based on a gaseous reaction principle; or applying a gasification technique, centered on heterogeneous reaction [6]. The method chosen depends on the availability of feedstock and the intended downstream application. In terms of feedstock, reforming techniques are ideal for gases and light hydrocarbon liquids while gasification is generally reserved for heavier liquids and solids such as coal and biomass and when it comes to the downstream application, the ratio of $\mathrm{H}_{2}$ to $\mathrm{CO}$ in the final syngas will vary depending on the process used [6]. The lowest cost routes to syngas production, however, are based on natural gas as source [35]. These routes (Table 1) include: (i): steam reforming; (ii): partial oxidation; (iii): heat exchange/carbon-dioxide reforming; and (iv): autothermal reforming.

Table 1 summarizes these categories with examples. It shows, among other things, the different syngas composition ratios obtainable by substantially different routes. The "conventional" steam reforming (the subject of interest in this paper) produces syngas with $\mathrm{H}_{2} / \mathrm{CO}$ ratio of 3 ; partial oxidation produces a ratio of 2; while $\mathrm{CO}_{2}$ reforming produces a ratio of 1 . These different ratios are the ideal feedstocks for ammonia, methanol, and oxo chemicals production respectively. Note that routes (i) and (ii) are essentially one-step synthesis (though not necessarily elementary one-step reactions). By contrast, Table 1 highlights an alternative multi-step (it is believed) path, that can give a variable $\mathrm{H}_{2} / \mathrm{CO}$ ratio in the range of 2-4 itself, suggesting an inherent flexibility in that pathway without a major change in the reaction path or condition. In fact, for each of the routes in Table 1, syngas composition can be adjusted to desired ratios by various ways, for example, altering process conditions such as feedstock ratio, operating conditions, etc. [35]. Other options for achieving this include the use of shift converters also known as water gas shift reaction [39], as well as the use of adsorption mediums such as PSA (pressure swing adsorbers), membranes and molecular sieves [40]. As a result, a range of $\mathrm{H}_{2} / \mathrm{CO}$ ratios can exist for each process (Table 2).

Steam reforming of natural gas is advantageous over partial oxidation and authothermal reforming in 


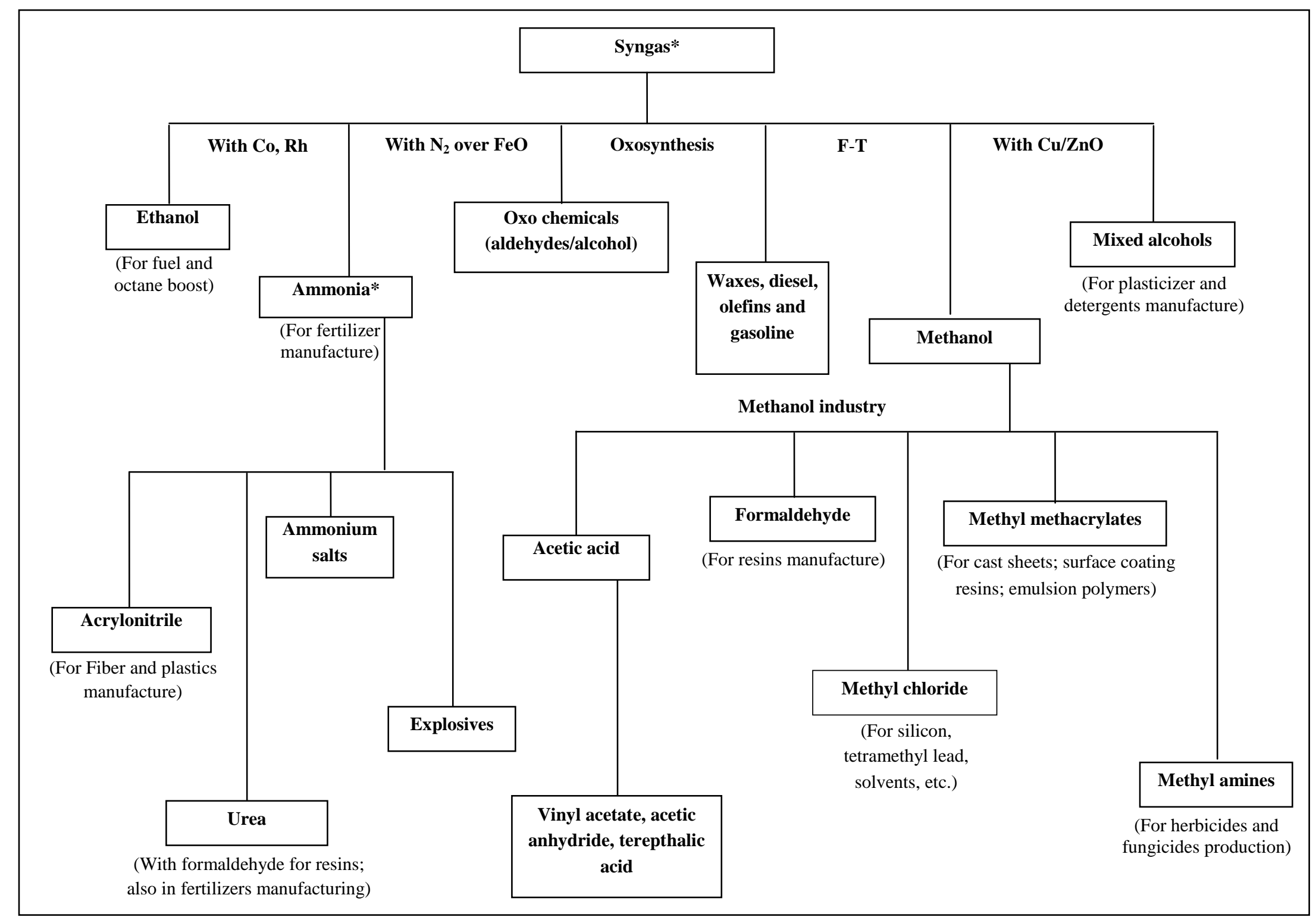

Fig. 1 Syngas routes to vast range of viable chemical products $(* 6,34,38])$. 
Table 1 Syngas production routes and applications.

\begin{tabular}{|c|c|c|c|c|}
\hline Process & Reaction paths & $\Delta \mathrm{H}_{298}$ & $\mathrm{H}_{2} / \mathrm{CO}$ ratio & Typical application \\
\hline $\begin{array}{l}\text { (i): SMR } \\
\text { (steam reforming) }\end{array}$ & $\mathrm{CH}_{4(\mathrm{~g})}+\mathrm{H}_{2} \mathrm{O}_{(\mathrm{g})} \rightleftharpoons \mathrm{CO}_{(\mathrm{g})}+3 \mathrm{H}_{2(\mathrm{~g})}$ & 206 & 3 & Ammonia plant feed; $\mathrm{H}_{2}$ production \\
\hline $\begin{array}{l}\text { (ii): POX } \\
\text { (partial oxidation) }\end{array}$ & $\mathrm{CH}_{4(\mathrm{~g})}+\frac{1}{2} \mathrm{O}_{2(\mathrm{~g})} \rightleftharpoons \mathrm{CO}_{(\mathrm{g})}+2 \mathrm{H}_{2(\mathrm{~g})}$ & -38 & 2 & Methanol production; F-T process \\
\hline (iii): $\left(\mathrm{CO}_{2}\right)$ reforming & $\mathrm{CH}_{4(\mathrm{~g})}+\mathrm{CO}_{2(\mathrm{~g})} \rightleftharpoons 2 \mathrm{CO}_{(\mathrm{g})}+2 \mathrm{H}_{(\mathrm{g})}$ & 247 & 1 & $\begin{array}{l}\text { Aldehyde and alcohols manufacture } \\
\text { (oxosynthesis) }\end{array}$ \\
\hline $\begin{array}{l}\text { (iv): ATR } \\
\text { (autothermal reforming) }\end{array}$ & $\begin{array}{l}\mathrm{CH}_{4(\mathrm{~g})}+\frac{3}{2} \mathrm{O}_{2(\mathrm{~g})} \rightleftharpoons \mathrm{CO}_{(\mathrm{g})}+2 \mathrm{H}_{2} \mathrm{O}_{(\mathrm{g})} \\
\mathrm{CH}_{4(\mathrm{~g})}+\mathrm{H}_{2} \mathrm{O}_{(\mathrm{g})} \rightleftharpoons \mathrm{CO}_{(\mathrm{g})}+3 \mathrm{H}_{2(\mathrm{~g})} \\
\mathrm{CO}_{(\mathrm{g})}+\mathrm{H}_{2} \mathrm{O}_{(\mathrm{g})} \rightleftharpoons \mathrm{CO}_{2(\mathrm{~g})}+\mathrm{H}_{2(\mathrm{~g})}\end{array}$ & Thermo-neutral & $1.8-3.8$ & $\begin{array}{l}\text { Applicable in any of the above } \\
\text { production, but most commonly } \\
\text { used for hydrogen manufacture. }\end{array}$ \\
\hline
\end{tabular}

Table 2 Range of $\mathrm{H}_{2} / \mathrm{CO}$ ratios possible for some syngas production routes.

\begin{tabular}{ll}
\hline Process & Typical $\mathrm{H}_{2} / \mathrm{CO}$ range \\
\hline (i) SMR & $2.8-4.8$ \\
(ii) POX & $1.8-2.0$ \\
(iii) Steam reforming with pre-reformer & $2.2-4.2$ \\
\hline
\end{tabular}

the sense that it does not require oxygen as feedstock which is expensive when cryogenically produced. Although partial oxidation has the advantage of being able to utilize any available hydrocarbon (even those with high sulfur contents), carbon removal from the product gas is required, an operation superfluous with steam reforming. Rapid carbon deposition is also a demerit in $\mathrm{CO}_{2}$ reforming, which is a highly endothermic process, but this process produces higher purity $\mathrm{CO}$. As to the relative economic advantages of these paths, they are broadly competitive and most have found patronage by certain major companies over time. The non-catalytic partial oxidation process (route (ii) in Table 1) is currently being used by Texaco and Shell for the production of hydrogen [41] while companies like ICI (imperial chemical industries) and Exxon (former Standard Oil) produce syngas by the autothermal process, which is a combination of steam reforming and partial oxidation, in a bid to reconcile the heat requirements of the endothermic steam reforming process by heat exchange with the exothermic partial oxidation.

\section{Industrial Application of Syngas}

Over two-third of the syngas generated worldwide is used to produce hydrogen which in turn is used to synthesize ammonia for the fertilizer industry, or put to use in petroleum refineries, where it plays an important role in processes such as hydrotreating and desulfurization [6]. The second largest market segment is syngas used for the production of methanol including dimethyl ether. A valuable resource in the CPI, methanol is also deployed as a synthetic fuel, and can be converted to olefins such as propylene via MTP (methanol-to-propylene) technology as an alternative to propylene production from crude oil [34]. A smaller fraction of global syngas output-less than 5\%, contributes to chemical products or F-T synthetic fuels, while only a small fraction of all syngas produced is used as a SNGs (ubstitute for natural gas) or in IGCC (integrated gasification combined cycles) for power production [6].

Methanol Production from Syngas: Methanol production is chosen for consideration because the process shows good economics, especially since methanol is a highly versatile material (Fig. 1). Methanol has economic stability and a steady growth rate owing to the low costs of production and diversity of applications. Also, methanol production is the third largest user of natural gas in the world [42], and is currently being considered and investigated for operation in Nigeria.

Process Summary: Methanol does not occur in its free state in nature and was first manufactured in the 
17th century by the destructive distillation of wood [34]. The modern industrial production of methanol is chiefly based on the catalytic reduction of $\mathrm{CO}\left(\right.$ or $\left.\mathrm{CO}_{2}\right)$ by hydrogen. Production consists of three basic operations: (1) syngas preparation; (2) methanol synthesis; (3) methanol purification. The main variable in the method of production is the source of feed gas (syngas), which may be natural gas, coal, or naphtha. Methanol synthesis and purification steps are essentially similar in all methods of production. Methanol synthesis step occur according to the reaction:

$$
\mathrm{CO}_{(\mathrm{g})}+2 \mathrm{H}_{2(\mathrm{~g})} \rightleftharpoons \mathrm{CH}_{3} \mathrm{OH}_{(\mathrm{l})} \Delta \mathrm{H}_{298}=-91 \mathrm{KJ} / \mathrm{mol}
$$

This step relies upon a copper-based catalyst $\left(\mathrm{Cu} / \mathrm{ZnO} / \mathrm{Al}_{2} \mathrm{O}_{3}\right)$ that gives good yield of methanol at pressures of 50-100 atm. These pressures are substantially below those of the 250-350 atm range required by earlier processes using mixed zinc and chromium oxide catalysts. This low pressure synthesis process (developed by ICI) occurs at relatively low temperatures of $250-270{ }^{\circ} \mathrm{C}$ compared to the $300-400{ }^{\circ} \mathrm{C}$ operating temperatures of the earlier processes. Product purification is by conventional distillation methods.

Economic considerations usually favor the steam-reforming of natural gas route for syngas preparation for production of methanol. Therefore, this method has become the most preferred today. Asberg-Petersen, et al. [43] assesses the economics of this method in comparison with that involving naphtha (steam-naphtha) reforming, and found that natural gas route is more economical. Coal was not used for the assessment as it is hardly ever used today in commercial production of methanol production for economic reasons, and even industries that had utilized this as feed are progressively switching to petroleum sources. Methanol production is economically more advantageous in Nigeria than other industrialized countries because of the practically-free abundantly-available natural gas resource in the country [44]. As a matter of fact, the cost value of natural gas is attained by piping, metering, natural gas purification costs, etc., during gas processing.

Most industrialized nations of the world have realized the economic potentials of natural gas and have since been utilizing this feedstock, and indeed the steam reforming of natural gas process, as syngas source for chemical synthesis. To what extent then is Nigeria using this viable method of utilizing its otherwise wasted natural gas resource. This is discussed in the next section.

\section{The Regrettable Absence of Syngas use in the Nigerian Petrochemical Industry}

The economy of the developed countries of the world depends to a marked degree on the availability and cost of raw materials and energy for industrial and domestic purposes. Where there is insufficient raw material locally, there is reliance on importation which is negative (causes trade deficit hence foreign currency debt) for countries that find themselves in that category. As a substantial proportion of industrial products- polymers, detergents, fertilizer, pharmaceuticals, synthetic fibers, etc., depend on the supply of basic organic chemicals or petrochemicals as raw materials for their synthesis, more countries are manufacturing these chemicals by syngas route from available natural resources. For example, ammonia, ammonium nitrate and urea production in most parts of the world, GTL technology in South Africa for the production of liquid fuels, oxygenates and oxo chemicals manufacture in the USA and Europe and, methanol production in New Zealand. All these utilize natural gas (via syngas) for their production. By contrast, while Nigeria is a direct or indirect consumer of products from these processes, she hardly makes any domestically and unfortunately relies too much on importation. Although Nigeria is endowed with large proven natural gas reserves and is in an advantageous position to make syngas - the principal feedstock for the manufacture of these and other products [45].

Nigeria is the largest holder of natural gas proven reserves in Africa and the ninth largest holder in the 
world. Nigeria's proven natural gas reserves is estimated as 187 tcf [1] but a reported $13 \%$ of the 168 billion cubic meters of natural gas flared worldwide (second largest amount of gas flared globally) come from Nigeria [46]. Probably less than 5\% of the gas goes into syngas production and its derivative products manufacture in Nigeria. Virtually all natural gas commercially utilized in Nigeria is exported as LNG. Although Nigeria has three petrochemical plants in operation, assessment shows that a limited range of products are obtained from them despite the fact that there are over 2,500 chemical products derivable from petroleum sources [38]. Table 3 summarizes the production fact of the Nigerian petrochemical industry. It furtherly shows that the Nigerian petrochemical industry fully operates one aspect of petrochemical industry - the production and separation of basic raw materials such as ethylene propylene, benzene-but are clearly deficient in further downstream processing - the conversion of these raw materials into the numerous chemical compounds of commercial significance. It is also observed that no petrochemical sector in Nigeria utilizes natural gas $\left(\mathrm{CH}_{4}\right)$ as principal raw material. All their feedstocks are light hydrocarbon liquids rather than natural gas. The closest related gas utilization process in the industry involves the conversion of NGL at IEPCL (Indorama Eleme Petrochemicals) by steam cracking, with syngas being formed in the furnace along with other compounds in a high $\mathrm{H}_{2} / \mathrm{CO}$ ratio. The hydrogen product is exported after liquefaction, which is done outside battery limits, with a little portion used in the plant. The $\mathrm{CO}$ produced is also used in the plants for the control of catalyst activity in the acetylene-to-ethylene converters.

\section{Syngas Production at IEPCL}

As shown in Table 3, of the three petrochemical complexes operational in Nigeria (i. e., WRPC (Warri Refining and Petrochemical Company), KRPC (Kaduna Refining and Petrochemical Company) and Indorama-Eleme Petrochemical Company , only IEPCL utilizes natural gas and steam as feedstock for production. Therefore, in assessing the extent of steam reforming of natural gas in the Nigerian context, IEPCL is used as a basis.

Table 3 The nigerian petrochemical industry: production facts [47].

\begin{tabular}{|c|c|c|c|c|c|c|}
\hline Industry & Feedstock & $\begin{array}{l}\text { Source of } \\
\text { feedstock }\end{array}$ & $\begin{array}{l}\text { Conversion } \\
\text { process }\end{array}$ & $\begin{array}{l}\text { Intermediate } \\
\text { products }\end{array}$ & End-products & Uses \\
\hline \multirow{2}{*}{$\begin{array}{l}\text { 1. NNPC polypropylene } \\
\text { and carbon black plant, } \\
\text { Ekpan, Delta State. }\end{array}$} & $\begin{array}{l}\text { Propane- } \\
\text { propylene } \\
\text { mixture }\end{array}$ & \begin{tabular}{|l} 
NNPC \\
refinery, \\
Warri, Delta \\
State \\
\end{tabular} & $\begin{array}{l}\text { Catalytic } \\
\text { polymeri-zati } \\
\text { on }\end{array}$ & Propylene & $\begin{array}{l}\text { Polypropylen } \\
\text { e }\end{array}$ & $\begin{array}{l}\text { Making woven sacks, bottle, } \\
\text { crates, floor carpets, } \\
\text { packages and other plastic } \\
\text { goods. }\end{array}$ \\
\hline & $\begin{array}{l}\text { Residual oil } \\
\text { (decant oil) }\end{array}$ & $\begin{array}{l}\text { NNPC } \\
\text { refinery, } \\
\text { Warri, Delta } \\
\text { State }\end{array}$ & $\begin{array}{l}\text { Pyrolysis (oil } \\
\text { furnace } \\
\text { process) }\end{array}$ & & Carbon black & $\begin{array}{l}\text { Tyres and tubes for cars, } \\
\text { hoses, gaskets foot wear, } \\
\text { carbon paper, ink, etc. }\end{array}$ \\
\hline $\begin{array}{l}\text { 2. Indorama-eleme } \\
\text { petrochemical complex, } \\
\text { phase II. (indorama eleme } \\
\text { petrochemical company } \\
\text { limited, IEPCL)*. } \\
\text { Eleme, Rivers state }\end{array}$ & $\begin{array}{l}\text { NGL; } \\
\text { propylene } \\
\text { rich feed } \\
(\mathrm{PRF})\end{array}$ & $\begin{array}{l}\text { AGIP, Port } \\
\text { harcourt; } \\
\text { NNPC } \\
\text { refinery, Port } \\
\text { Harcourt, } \\
\text { Rivers State }\end{array}$ & $\begin{array}{l}\text { Steam } \\
\text { cracking and } \\
\text { catalytic } \\
\text { polymeri-zati } \\
\text { on }\end{array}$ & $\begin{array}{l}\text { Ethylene; } \\
\text { propylene; } \\
\text { ethylene } \\
\text { terephthalate }\end{array}$ & $\mid \begin{array}{l}\text { Polyethylene } \\
\text { polypropylen } \\
\text { e }\end{array}$ & $\begin{array}{l}\text { Making refuse bags; } \\
\text { wrappers for packaging; } \\
\text { industrial drums and } \\
\text { containers; pharmaceutical } \\
\text { and cosmetic bottles; } \\
\text { roofing sheets; cable } \\
\text { insulation etc. }\end{array}$ \\
\hline $\begin{array}{l}\text { 3. NNPC } \\
\text { petrochemicallinear } \\
\text { alkyl-benzene plant, } \\
\text { Kaduna, Kaduna State }\end{array}$ & $\begin{array}{l}\text { Kerosene } \\
\text { fractions } \\
\text { reformate }\end{array}$ & $\begin{array}{l}\text { Kaduna } \\
\text { refinery, } \\
\text { Kaduna, } \\
\text { Kaduna State }\end{array}$ & $\begin{array}{l}\text { Alkylation } \\
\text { (fiedel-craft's } \\
\text { ) }\end{array}$ & $\begin{array}{l}\text { Linear } \\
\text { olefins; } \\
\text { benzene }\end{array}$ & \begin{tabular}{|l|} 
Linear alkyl \\
benzene; \\
heavy \\
alkylates kero \\
solvent
\end{tabular} & $\begin{array}{l}\text { Detergents, aviation } \\
\text { gasoline, aromatic solvent, } \\
\text { lubrication oil, greases, } \\
\text { thermal fluids insecticides, } \\
\text { nail varnish }\end{array}$ \\
\hline
\end{tabular}

*Indorama Group acquired and revamped Eleme Petrochemical, which was a subsidiary of NNPC. 
IEPCL plant produces mainly ethylene and propylene (as intermediate products) using natural gas feedstock (NGL to be precise), for final polymerization to polyethylene and polypropylene. The plant uses natural gas feed for the manufacture of only ethylene and propylene (petrochemicals) in commercial quantity among the over 2,500 petrochemicals possible via syngas. This is disappointing especially since Nigeria still flares natural gas in large quantity as "waste".

The petrochemical complex consists of three plants namely: the olefins plant, polyethylene plant, and polypropylene plant (currently there is polyethylene terephthalate plant). The olefins plant is the site for NGL conversion of olefins by steam cracking (uncatalyzed thermal cracking with steam) at a capacity of 240,000 MT/year and 95,000 MT/year of ethylene and propylene products respectively; while the polyethylene and polypropylene polymerize the products of the olefins plant to yield ethylene and propylene polymers.

The conversion reactions of interest in this work (i.e. NGL to ethylene and propylene) occur in the pyrolysis furnace of the olefins plant. Here, $\mathrm{NGL}\left(\mathrm{C}_{4}\right.$ and lighter compounds) is cracked at temperatures of about $890-900{ }^{\circ} \mathrm{C}$ in the presence of steam (and dimethyl disulphide, which suppresses coke formation). The reactions are uncatalyzed and are quenched by cooling effluent immediately after pyrolysis which occurs in a matter of milliseconds. Major cracking reactions occurring in the furnace to yield the desired olefin products (ethylene and propylene) include:

$$
\begin{aligned}
\mathrm{C}_{4} \mathrm{H}_{10(\mathrm{~g})} & \rightleftharpoons 2 \mathrm{C}_{2} \mathrm{H}_{4(\mathrm{~g})}+\mathrm{H}_{2(\mathrm{~g})} \\
\mathrm{C}_{4} \mathrm{H}_{10(\mathrm{~g})} & \rightleftharpoons \mathrm{C}_{3} \mathrm{H}_{6(\mathrm{~g})}+\mathrm{CH}_{4(\mathrm{~g})} \\
\mathrm{C}_{3} \mathrm{H}_{8(\mathrm{~g})} & \rightleftharpoons \mathrm{C}_{3} \mathrm{H}_{6(\mathrm{~g})}+\mathrm{H}_{2(\mathrm{~g})} \\
\mathrm{C}_{3} \mathrm{H}_{8(\mathrm{~g})} & \rightleftharpoons \mathrm{C}_{2} \mathrm{H}_{4(\mathrm{~g})}+\mathrm{CH}_{4(\mathrm{~g})} \\
\mathrm{C}_{3} \mathrm{H}_{8(\mathrm{~g})} & \rightleftharpoons 3 \mathrm{C}_{(\mathrm{s})}+4 \mathrm{H}_{2(\mathrm{~g})}
\end{aligned}
$$

Other thermodynamically possible reactions occur, yielding a variety of co-products including syngas, coke (or carbons), $\mathrm{H}_{2} \mathrm{~S}, \mathrm{CO}_{2}$, paraffin and aromatics. Therefore, in order to keep the furnace yields at desirable composition, certain process conditions are controlled namely feedstock composition, severity of crack, residence time, and hydrocarbon partial pressure. The presence of steam, albeit for the cracking reaction, encourages syngas formation by steam-methane reforming $\left(\mathrm{CH}_{4(\mathrm{~g})}+\mathrm{H}_{2} \mathrm{O}_{(\mathrm{g})} \rightleftharpoons\right.$ $\left.\mathrm{CO}_{((\mathrm{g})}+3 \mathrm{H}_{2(\mathrm{~g})}\right)$ and coke gasification, $\left(\mathrm{C}_{(\mathrm{s})}+\right.$ $\left.\mathrm{H}_{2} \mathrm{O}_{(\mathrm{g})} \rightleftharpoons \mathrm{CO}_{(\mathrm{g})}+\mathrm{H}_{2(\mathrm{~g})}\right)$ side reactions. The resulting syngas consists of $\mathrm{CO}$ and $\mathrm{H}_{2}$ comprising about $0.03 \mathrm{~mol} \%$ and $0.08 \mathrm{~mol} \%$ respectively of the effluent gas mixture (furnace effluent rate $=4,290 \mathrm{kmol} / \mathrm{h}$ ). The quantity of syngas produced is so small that it is insufficient in meeting the requirement of the plant: $\mathrm{CO}$ used to control catalyst activity in the hydrogenation reactors is supplemented by purchase; other reactions occurring in the furnace contribute to the total hydrogen product (about $28 \mathrm{~mol} \%$ of effluent) that is used for hydrogenation purposes in the plant and for export.

By what means then does Nigeria obtain the chemical products used in the country? What exactly are the factors working against effective gas utilization especially for chemical synthesis? What steps are being taken to ensure better gas utilization in the future, particularly for the development of the Nigerian Petrochemicals Industry?

\section{Status of Steam Reforming of Natural Gas in Nigeria}

As discussed in the previous sections, not only is natural gas a major clean-burning energy source, but also by its transformation to $\mathrm{CO}-\mathrm{H}_{2}$ mixtures (syngas), it has become a major feedstock for chemicals production. Most industrialized nations, for example, the USA, Germany and even South Africa (has to import natural gas from Mozambique) utilize this low cost gas resource as feedstock to major petrochemicals because of syngas better economics compared to naphtha or coal.

It can thus be argued validly that natural gas reforming and the myriads of downstream 
petrochemicals, it has engendered, have contributed substantially to growth and development of those countries. Nigeria is a country with large trade (especially chemical trade) deficits and could use some of these natural-gas-based petrochemicals with abundant and cheap natural gas in the country. Nigeria has the potential to turn the aforementioned trade deficit into a surplus while gaining additional advantages like enhanced industrialization and employment. For a country ranking 10th among gas-bearing nations (with an estimated 187 tcf of natural gas reserve; about 10 times its crude oil reserves), it is regrettable that such self-sufficiency is not already the case. Reports show that only a small percentage of the gas produced is gainfully used (about $35 \%$ of which $12 \%$ is re-injected to enhance oil recovery). The remaining $(65 \%)$ is flared at production well-heads. This translates to a huge waste when weighed against the natural-gas-to-petrochemicals option.

The ineffective gas utilization in Nigeria could be attributed to a number of factors including wrong national economic priorities caused by an inadequate awareness at national policy making and executive levels. Other disincentives to flourishing of the natural gas-to-petrochemicals industry in Nigeria include a hostile business environment that discourages private, domestic and foreign investment. Examples include poor infrastructure such as unsteady and insufficient electric power supply, an under developed domestic consumer market for the petrochemical end-products, and until recently, insufficient economic incentives from government (such as tax concessions) temporary exemptions, deregulated markets and freedom to repatriate profits.

The Nigerian government has however begun to realize the necessity in providing these incentives for gas-sector development. By setting some incentives in place, for example, high capital allowance, investment tax credits and alternative funding for gas projects and also with polices like the "flare elimination by 2008 ",
"The Gas Revolution, Rebirth of Nigeria's Industrialization" and others. The government has promoted gas utilization in the country, as major oil producing companies and others are now executing gas projects. For example, the Chevron-Sasol's GTL project, Mobil's OSO NGL project, Shell's Odidi gas project, Indorama's gas to fertilizer and gas-to-petrochemical projects, Elf's Obite gas project, Akwa Ibom gas plant and Ovia's $\$ 1.5$ billion methanol and petrochemical plant. The full implementation of the entire Gas Master Plan will result in about $\$ 25$ billion worth of investments in gas processing, transmission and downstream gas utilization projects. The project will facilitate the establishment of one major petrochemical plant, two fertilizer plants, five fertilizer's blending plants, a methanol plant and a liquefied petroleum gas distribution plant. To the best of the authors' knowledge, however, no project for the development of the petrochemical industry by natural gas conversion has been in operation apart from the Indorama Petrochemical.

As highlighted in this paper, steam reforming of natural gas is one of the promising methods for conversion of natural gas to petrochemicals, and has been utilized in various industrialized countries for this purpose. Besides being economical, this process provides a wide array of highly demanded consumer products most of these products, example methanol, hydrogen and ammonia, are themselves invaluable feed stocks for consumables manufacture. Such a natural gas-to-syngas based industrialization in Nigeria, in addition to meeting domestic chemical and drugs needs of the country, would also boost export and hence reduce or eliminate Nigeria's vexing trade deficit while providing the additional benefit of enhanced employment. For example, according to the Stokes consulting Group [42], if a steam reforming plant, say methanol production, was built in Nigeria with production capacity of at least 5,000 tons/day, it would use about 170 million standard cubic feet per 
day of natural gas and employ about 50 people directly in the plant (excluding employment for methanol sales and distribution). Also, at the time of construction, there would be about 200-300 people employed. Furthermore, in downstream manufacture of derivatives such as formaldehyde or acetic acid, wealth creation and employment could be ten times that obtainable in the methanol production only, and since the number of such derivative downstream products is huge, the multiplier employment effect and economic benefits would be in many orders of magnitude greater. Also, industries relying on these petrochemicals feedstock (including pharmaceutical, plastics and fertilizer industries) would sprout up in the country because of the proximity to and availability of feedstock material.

\section{Conclusions}

Nigeria's achievements in utilizing natural gas reserves include Nigeria LNG plant, Brass LNG Plant, Escravos GLT Plant, Bonny Non-Associated Gas Plant, West Niger Delta LNG Plant, Olokola LNG Project, Bonny Island Gas and Power Plant, Nigeria Gas Company, Akwa Ibom gas plant, Ovia’s \$1.5 billion methanol and petrochemical plant and some thermal power plants. These projects have not reached operational stage as most of the projects employ LNG route to utilize natural gas for export; this only generates revenue with no industrialization prospect; hence, gas utilization in Nigeria is still inadequate when compared to those of other oil and gas producing nations.

Many industrialized nations, for example the USA, have experienced huge economic benefits from such natural gas-to-petrochemicals processes, via syngas, even at relatively higher natural gas costs. Nigeria therefore, having a practically free and abundant source of natural gas, should possess a highly developed petrochemical industry by natural gas conversion processes. Although this is not yet the case, implementation of natural gas-to-syngas processes, like steam reforming of natural gas, would contribute substantially in taking the country to high levels of industrialization.

Steam reforming of natural gas has been highlighted as an option for optimized NG utilization in Nigeria. This is because of the potentially subsequent industrialization attainable by its application for petrochemicals' manufacture, as well as the good economics obtainable by the process (judging from the literature and by the world-wide preference for the process in many applications). Such production process will therefore help Nigeria reduce its chemical trade deficit, as most of the country's chemical needs such as drugs, specialty plastics, and even fertilizers (currently being imported with scarce foreign exchange from overseas, where they are produced from petroleum sources of which Nigeria exports raw) will be manufactured in the country. This also puts Nigeria in the position as an exporter of these chemical products. The gas master plan is an effort to accelerate gas development, given uncertainties around crude oil and quantity of gas in Nigeria. An active gas sector will increase foreign exchange earnings, boost job opportunities and other multiplier effects.

\section{Recommendations}

Steam reforming of natural gas should be considered for implementation in Nigeria by capable international companies of reputation. This project should not be considered for execution by the government alone, as the government has limited resources (especially with its current debt of more than 6.6 billion dollars) and is therefore ill- positioned to engage in such multi-billion dollar investment. Besides, the government has a poor record of failed projects including the ONNE fertilizer plant (NAFCON), ALSCON (Aluminium smelting company), Ajaokuta steel plant, and the Refineries. Even the existing petrochemical industry, also government-controlled is a bit of a disappointment in 
terms of its limited range of products (case of Indorama Eleme Petrochemical Ltd versus the Government-owned WRPC and KRPC).

The government can assist by creating an enabling environment for gas conversion process development required by investors, especially foreign investors, since most indigenous investors lack the technology and capital to carry out most of these projects which usually required huge investment to initiate. To achieve this, the government needs to provide better policies and incentives for these investors such as temporary tax exemptions; profits-repatriation permits, and deregulated markets.

The government also needs to focus its attention on fighting the endemic corruption and political instability of the nation, which have been major contributors to the failure of the afore-mentioned government-controlled projects; and also on improving the nation's basic infrastructure, like power supply and telecommunications; infrastructure imperative to the industrialization of any nation.

\section{References}

[1] Appah, D. 2014. "Energy Challenge for Nigeria Industrial Revolution Plan: the Way Forward." Presented at the 44th Annual Conference of Nigerian Society of Chemical Engineers, Owerri, Nigeria.

[2] Ikoku, C. I. 1992. Natural Gas Production Engineerin. FL: Kireger Publishing Company.

[3] Patel, B. 2005. Gas Monetization: A Techno-Economic Comparison of Gas-to-Liquids and LNG. Presented at the 8th World Congress of Chemical Engineers, Glassglow, UK.

[4] Cottrill, A. 2002. "Gas-to-Liquids Makes Move to Step up a League: World-Scale Proposals Start to Drive Forward." Up-stream: 26.

[5] Nexant, P. 2007. "LNG: The Expanding Horizons of Liquefaction Technology and Project Execution Strategies." Hydrocarbon Processing 8:46-9.

[6] Ulber, D. 2015. "A Guide to: Methane Reforming." Chemical Engineering Journal 122 (1): 40-6

[7] Folabi, L. 2004. "Options for Better Utilization of Natural Gas in Nigeria." NNPC quarterly Magazine 1:12-4.

[8] Younger, A. H. 2004. Natural Gas Processing Principles and Technology: Part 1. Alberta: Thimm Engineering Inc.

[9] CONOCO, 2002. "Conoco Gas Solution Offers New
GTL Technology for Economic Development of Stranded Gas Reserves." Accessed February 12, 2014. Http://www.conoco.com/pa/special/gtl.asp.

[10] Ross, F. P., and Walte, S. T. 2008. "Advanced Economics for Liquefied Natural Gas." Hydrocarbon Processing 1: 61-3.

[11] Campbell, J. M. 2004. "Gas Conditioning and Processing." In: The Equipment Modules, ed. 8th, Vol.2, USA: Campbell and Company.

[12] Holmen, A. 2009. "Direct Conversion of Methane to Fuels and Chemicals." Catalysis Today 142: 2-8

[13] Hunter, T., Serrani, A., Bandoni, J., and Brignole, E. 1997. "Automatic Design and Optimization of Natural Gas Plants.” Ind. Eng. Chem. Res. 36: 2715-24.

[14] Zhang, B., Yang, J., Wang, J., Chou, L., Song, H., Zhao, J., and Li, S. 2006. "Comparative Study on Oxidative Coupling of Methane to Ethane and Ethylene over $\mathrm{Na}_{2} \mathrm{WO}_{4}-\mathrm{Mn} / \mathrm{SiO}_{2}$ Catalysts Prepared by Different Methods." Journal of Molecular Catalysis A: Chemical 245 (1-2): 272-7.

[15] Abedi, A. A. 2007. "Economic Analysis of a new Gas-to-Ethylene Technology." Master Thesis. Department of Chemical Engineering, Texas A \& M University: College Station, Texas.

[16] Aasberg, P. K., Nielsen, C. S., and Dybkjær, P. J. 2009. "Large Scale Methanol Production from Natural Gas." Haldor Topsoe. Accessed January 9, 2015. http://www.topsoe.com/business_areas/methanol.

[17] ICRC. 2001. "ICRC Leads Gas-to-Liquid Ultra-Clean Fuels Project Team." Accessed: June 1, 2014. http://www.icrc-hq.com/pmel.htm.

[18] Ahmad, I. M., Zughaid, M., El, A., and Mohammed, G. A. 2002. "GTL (Gas-to-Liquid) Technology: New Energy Technology for the Third Millennium.” SPE Paper 78573. Presented at the 10th Abu Dhabi International, United Arab Emirates.

[19] Font, F. J., Gamlin, T., and Ashley, M. 2003. "The Ultimate Clean Fuel-Gas-to-Liquids Products." Hydrocarbon Processing 2: 52-8.

[20] Rahman, O. A., and M. Al-Masamani, G. E. 2004. "GTL: Is it an Attractive Route for Gas Monetization?" SPE Paper 88642. Presented at the 11th Abu Dhahi International Petroleum Exhibition and Conference: Abu Dhahi International Petroleum Exhibition and Conference: Abu Dhahi, UAE.

[21] Apanel, G. 2005. "GTL Update." SPE Paper 93580. Presented at the 14th SPE Middle East Oil and Gas Show and Conference, Bahrain International Exhibition Centre, Bahrain.

[22] Rahmin, I. I. 2005 “GTL Prospects: Stranded Gas, Diesel Needs Push GTL Work.” Oil and Gas Journal: 235-47.

[23] Hall, K. R. 2005. A New GTL (Gas to Liquids) or GTE 
(Gas to Ethylene) Technology." Catalyst Today 106:243-6.

[24] Jager, B. 2003. "The Development of Commercial Fischer-Tropsch Reactors." Presented at the American Institute of Chemical Engineers, Spring National Meeting, New Orleans, LA.

[25] Thackeray, F. 2003. "F-T GLT Approaches Threshold." Paper 13563. Presented at the World Petroleum Congress.

[26] Storch, H. H., Golumbic, N., and Anderson, R. B. 1951. The Fischer-Tropsch and Related Synthesis. New York: Wiley.

[27] Fleisch, T. H., Sills, R. A., and Briscoe., M. D. 2002. "2002-Emergence of the Gas-to-Liquids Industry: a Review of Global GTL Developments." Journal of Natural Gas Chemistry: 34-6

[28] Shell, C. 2003. "Stepping on the Gas." Shell Chemicals Magazine (Springs 2003). Accessed: July 5, 2014.

Http://www.shellchemicals.com/chemicals/magazine/arti cle/1,1261,116gen-page-id=856,000 html.

[29] Madaki, O. A. 2005. "The Nigerian Oil and Gas Industry from Joint Ventures to Production Sharing Contracts." African Renaissance Journal: 27-9.

[30] Kehinde, A. 2014. "Strategy for the Development of the Petrochemical Industry in Nigeria." Presented at Chemical Engineering Department, University of Lagos, Nigeria.

[31] Mall, I. D. 2007. Petrochemical Process Technology. India: Macmillan India Ltd.

[32] Debussy, J. H. 1972. Materials and Technology: Petroleum and organic Chemicals." London: Longman 4: 76-276.

[33] Considine, D. M. 1974. Chemical and Process Technology Encyclopedia. McGraw-Hill: 107-8, 595, 793, 1077.

[34] Matar, S. 2000. Chemistry of Petrochemical Processes, 2nd. ed. Texas: Gulf Publishing.

[35] Spath, P. L., and Dayton, D. C. 2003. "Technical and Economic Assessment of Syngas to Fuels and Chemicals with Emphasis on the Potential of Biomass-Derived Syngas.” USA: National Renewable Energy Laboratory.
[36] Olah, G. A., Goeppert, A., and Surya, P. G. K. 2009. Beyond Oil and Gas: The Methanol Economy. England: Wiley-VCH Verlag GmbH and Co. KgaA.

[37] Stranges, A. N. 2003. "Germany's Synthetic Fuel Industry." Presented at the American Institute of Chemical Engineers Spring National Meeting, New Orleans, LA: 1927-45.

[38] Kent, J. A. 1974. Riegel's Handbook of Industrial Chemistry, 7th ed. Van Nostrand Reinhold: 514: 772-5.

[39] Goodger, F. M. 1980. "Alternative Fuels: Chemical Energy Resources.” Macmillan: 40-6.

[40] Cheng, H. C., and Hill, F. B. 1985. "Separation of Helium-Methane Mixtures by Pressure Swing Adsorption." AIChE Journal 31 (1): 95.

[41] Bland, W. F., and Davidson, R. L. 1967. Petroleum Processing Handbook. USA: McGraw-Hill:142-7.

[42] Stokes, C. A., and Stokes, H. C. 2002. "The Economics of Methanol Production in Nigeria Based on Large Low-cost Gas Resources." Florida: Stokes Consulting Group.

[43] Aasberg, P. K. O., and Nielsen, S. C. 2007. "Very large Scale Syngas Gas Production and Conversion to Methanol or Multiple Products." Stud. Surf. Sci. Cat. 167: 243.

[44] Davenport, B. 2002. Methanol, Chemical Economics Handbook Marketing Research Report. (Report number: 674.5000). SRI International, Menol Park, CA.

[45] Omomia, O. J. 2014. "Growth in Natural Gas Utilization in the Last Decade." Business Day Research and Intelligence Unit Report. Accessed October 11, 2014. www.businessdayonline.com/2014/03.

[46] Garba, I. M. 2007. "Phase-out of Gas Flaring in Nigeria by 2008: The Prospects of a Multi-Win Project (Review of the Regulatory, Environmental and Socio-Economic Issues)." Petroleum Training Journal. 4 (2): 99-136.

[47] NNPC. 1991. Operations Personnel Training Booklet for Petrochemical/Refining Facilities in Nigeria. Eleme Petrochemicals Company Ltd.

[48] OPEC (Organization of Petroleum Exporting Countries). 1997. Bulletin. OPEC: Vienna, Austria. 